\title{
Monoclonal Antibody E2.3
}

National Cancer Institute

\section{Source}

National Cancer Institute. Monoclonal Antibody E2.3. NCI Thesaurus. Code C2448.

A murine IgG1 monoclonal antibody directed ag ainst the human transferrin (Tf) receptor. Monoclonal antibody E2.3 binds to the Tf receptor, blocking the binding of transferrin to the receptor and resulting in decreased tumor cell growth. (NCI04) 